\title{
Administrative and Legal Forms of Regulation of the Modern Market of Space Services and Technologies
}

\author{
Dmytro Bezzubov
}

Doctor of Law, Associate Professor, State University of Infrastructure and Technology

(Kyiv, Ukraine)

E-mail: dbezzubov@ukr.net

https://orcid.org/0000-0001-7183-5206

Bezzubov, Dmytro (2020) Administrative and Legal Forms of Regulation of the Modern Market of Space Services and Technologies. Advanced Space Law, Volume 5, 14-24. https:// doi.org/10.29202/asl/2020/5/2

The relevance of the topic is primarily due to the fact that at the current stage of development of the world economy, a number of contradictions have arisen between the qualitatively new state of the world market and the inadequacy of existing mechanisms and methods of its legal regulation. Scientific development of modern problems of legal regulation of the world market of space services and technologies is extremely relevant today in connection with the significant diversification of applied areas of space activities, on the one hand, and with the increasing commercialization of these activities and the corresponding activation in relations in the world market of space services and technologies of the non - state sector, on the other.

Keywords: globalization, commercialization, space, technologies, market, services, International space station.

Received: February 23, 2020; accepted: March 25, 2020

\section{Introduction}

One of the main aspects of our time is the intensive processes of internationalization and globalization that take place in all spheres of human activity and have far-reaching consequences for the entire humanity. The immediate result of this comprehensive process is the formation of a global civil society whose material basis for existence is the world market and a unified international economic system. The world market of space services and technologies (hereinafter referred to as WMSST), which provides essential services and

(C) Bezzubov, Dmytro, 2020 
technologies for modern society, is an integral component of the world economic system, a part of the importance of which increases with the adoption of the concept of sustainable development.

International cooperation in the sphere of space services and technologies provision is an objective necessity due to a number of reasons of an economic, political, social, scientific, technical, and legal nature. This cooperation is a natural result of the transformation of space activities, which during the cold war were mainly focused on military purposes, and which, with the development of "warming" processes, is increasingly becoming an essential and necessary factor in the development of space science and its further progress, especially in its applied areas. Cooperation in the global space market should be considered as a real way to solve many global problems of humanity: environmental; energy; raw materials; information and communication (formation of a global information space and improving communications); monitoring of disarmaments; forecasting, prevention and elimination of the consequences of natural disasters, man-made and space disasters, and so on.

International space law (ISL), which historically arose as a set of special rules and principles of General international law governing the relationship of entities involved in the exploration and use of outer space, is now increasingly unable to regulate the harmonious social relations. At the beginning of the space age, the only subjects of space activities were exclusively states, which were later joined by international (intergovernmental) organizations. Therefore, the relevant branch of law, space law, was started as a branch of public international law. Today it consists of five main international acts (treaties) on space activities. As many sets of principles of some regions of this activity developed and adopted under the auspices of the United Nations, multilateral international agreements related to space activities and, thus, affect the state of legal regulation of relations in the world market of space services and technologies, several agreements on the establishment of international space organizations, that play a crucial role in the development of institutional mechanisms for regulating these legal relations, numerous multilateral and bilateral agreements on cooperation between states in certain areas of practical space activities, including agreements on cooperation in the provision of space services and others. These international legal instruments and decisions of international organizations for space activities (and the problems related to this activity) have largely determined the mechanisms of legal regulation of space activities; based on this legal base internationalization of space science and technology was getting more and more widely spread, and the global space market was finally founded. They became the legal basis for the continued development of international space law, as well as for the emergence and improvement of national space legislation.

The processes of commercialization of space activities has resulted in the rapid development of WMSST involving the operation of enterprises and organizations of the private sector, which has led in turn to a growing weight of international economic law and the active intervention of private international law in resolving the expanded circle of subjects of this market. Further development of WMSST, tightly associated with the operation of advanced space vehicles and often have global consequences, and also the consolidation of transnational corporations (TNCs), banks and private enterprises and organizations as the most active participants of relations on the territory of SMSST require the development of radically new approaches to questions of control over the actions of these economic entities at the national and international level, their legal status, state responsibility for space activities of subordinate legal entities, preventing harm and compensating for it, and so on. 
Considering the above and taking into account the exceptional role played by the ISL in settlement of relations between subjects of WMSST, on the one hand, and the improvement of national legislation, on the other, important is the fact that ISL as a relatively new branch of international law requires further development, especially given the processes of commercialization and diversification of relations in SMSST, with the appearance on the market of new subjects of space activities - international non-governmental organizations, private firms and transnational companies.

\section{The place and role of international institutions in regulating the modern market for space services and technologies}

The problems of adequacy of legal regulation of space activities have always been in the field of view of the world community. Therefore, it is quite natural that the United Nations and its specialized organizations have been dealing with the problems of legal regulation of relations between States in the field of space activities since the first steps of man into space. As a result, the United Nations Committee on the peaceful uses of outer space (CUOS), and first of all, its Legal Subcommittee, had accumulated the efforts of the world's leading lawyers in the first two decades of the space age, when the foundations of modern space law were laid a branch of public international law that regulates "the relations of States among themselves, with international intergovernmental organizations in connection with the implementation of all their space activities" (including in the vast world space market).

Despite the fact that from the first steps of man outside earth's atmosphere, the UNGA by its resolution 1148 (XII) concerning disarmament called for the conclusion of the international Convention on disarmament and at the same time to create a system of international monitoring intended to ensure the launching of objects through outer space exclusively for peaceful purposes (Oprishko, 1995), only in 1959, the Special Committee for outer space was founded, and in 1961 CUOS began its work. At the same time, the UNGA stressed that the UN should become the center of international cooperation in the exploration and use of outer space for peaceful purposes. However, the contradictions in the positions of the USSR and the United States on problematic issues of legal support for space activities did not immediately allow equal cooperation between the countries of the West and the East, and, in particular, in the direction of formulating norms and principles of space activities as the basis for international legal regulation of relations between subjects of space activities. In March 1962, taking into account the provisions of the UNGA mandate on the main tasks of its activities (scientifictechnical and legal problems of space activities), the UN Committee on outer space established its Scientific-technical and Legal subcommittees of the full membership. Since 1959, when the Committee had 24 member States, this UN body has grown significantly (to 61 members, Ukraine - since 1991), having received a fairly wide representation of intergovernmental and non-governmental organizations possessing the observer status in the Committee and its subcommittees.

The main issues that are constantly under the attention of the UN Committee on outer space and its subcommittees are: ensuring constant communication with governmental and nongovernmental organizations engaged in the exploration and use of outer space for peaceful purposes; exchanging information on space activities that can be submitted by governments on a voluntary basis; studying, developing and implementing activities for international cooperation in the field of outer space, as well as addressing legal problems arising in the 
course of space activities. The most significant achievements in the work of the Committee and the Legal Subcommittee are the theoretical research and development of the basic rules and principles of international space law, as well as international agreements in the field of space activities, in which these rules and principles are reflected.

The outer space Treaty remains the basis for legal regulation of relations between subjects of space activities. However, despite having a strong support in the world, the Treaty has not yet become truly universal, and the growth in the number of parties to it has slowed down in recent years, which is typical of the accession of States to the other four fundamental international legal instruments on space activities. This situation, as well as the interest of the world community in the further development of space science and technology, encouraged the Legal Subcommittee to come up with a proposal to assess the effectiveness of the five outer space treaties developed and adopted under the auspices of the United Nations.

In July 1997, the UN Secretary-General asked the member states of the world community to provide their conclusions on the factors that prevent States from joining the fundamental international legal acts on space activities. However, by this time, only 12 governments have sent the UN Secretariat (Osnovi, 1993) information on this issue, which objectively cannot give an adequate assessment of the community's attitude to the problem of the effectiveness of legal regulation of space activities, that is, to contribute to the synthesis and final determination of ways and means to solve the problem.

Some attempts to analyze the problems of legal regulation of space activities were made public at the world space forums of UN member States - UN Conferences on the peaceful uses of outer space. But neither the first (1968), nor the second (1982) conference focused primarily on the estimation of the level of development of space science and technology and the state of the practical use of space technologies, and also improvement of international cooperation level and the UN's role in the development of ISL, objectively could not see the prospects of commercial use of outer space and therefore did not highlight tendencies and issues of private sector participation in the provision of space services and technologies.

The third United Nations conference on the exploration and peaceful uses of outer space (UNISPACE III), which was held as well as the previous ones in the capital of Austria (1930 July, 1999), for the first time addressed the challenges facing the world community in connection with the commercialization of space activities and the increasing involvement of the private sector and transnational corporations in these activities. In this aspect, it is significant that for the first time, a space forum of this level was attended (along with representatives of 98 official delegations of UN member States) by more than 100 delegations of internationally recognized national non-governmental enterprises and organizations for the development, production, and operation of space technology, which were invited by the organizing committee of the Conference to participate in the forum as guests. In addition to summarizing the development of space activities since UNISPACE 82 (1982), publishing of information on national programs for the development of space science and technology, as well as reviewing ways to improve international cooperation in the development of world space activities, much attention was paid at the Conference to issues directly or indirectly related to the problems of WMSST, recognizing a certain crisis of space law in connection with the new conditions of space activities, primarily related to their commercialization and privatization.

The world forum reviewed the current state of development of the ISL, including the unsolved issues: a review and possible revision of the Principles relating to nuclear power sources in outer space; the definition and delimitation of outer space, as well as the use of 
the geostationary orbit (GSO), including consideration of ways and means for the rational and equitable distribution of GSO resources without harm to the role of the International telecommunication Union; and a review of the status of the five international legal documents on outer space.

At the same time, focusing on the importance of legal regulation of new areas of space activities, including those related to the increasing pragmatization of these activities and their accumulation within the framework of the WMSST, the Conference recommended that the UN Committee on outer space and its Legal Subcommittee analyze and submit proposals for new possible items on the agenda of the Legal Subcommittee through the Secretariat, namely: a comparative analysis of the principles of ISL and international environmental law; a review of existing international law that can be applied to space debris; legal aspects of space debris issue; an overview of the Principles of the use by States of artificial Earth satellites for international direct television broadcasting and the Principles relating to remote sensing of the Earth from space, for possible future conversion into contracts; improvement of the registration Convention; consideration of the Agreement on implementation of Part XI of the UN Convention on the sea law 10.12.1982 as a model to encourage wider accession to the Moon Agreement; commercial aspects of space activities (for example, issues of ownership, insurance and liability); revision of the concept of the "launching state".

Participants of the legal forum held within the framework of the Conference by the International Institute of space law stressed that $\mathrm{UN}$ member states need to consider possible frameworks for coordinating the rational use of global resources related to space activities. In this regard, States should focus particular attention on the diversity of needs, potential conflicts, the depletion of natural resources, value indicators of cost, and the activation of the privatization process in the field of space activities. According to many space industry experts who participated in the conference, the need to develop a Code of conduct related to space debris has already matured. For this purpose, the work already done in this area for the formation of possible models should be taken into account as much as possible.

With this in mind, the Legal Subcommittee, together with the Scientific -technical Subcommittee of the UN Committee on outer space, could consider this issue in the near future. To the vital issues of space activity regulation, it is also appropriate to add the problems of developing a legal regime for low earth orbits (LEO), taking into account recent changes in the Convention of the International telecommunication Union concerning the status of LEO as a limited natural resource and the protection of property in relation to space aircraft, for example, by developing an international list agreed with the UN Secretary-General's Register of space objects. UN member States should start discussing and finding solutions to the current legal problems as soon as possible and, in particular, recognize the need to take the most careful account of the fact that the role of private organizations and firms is expanding with the development of new legal norms.

\section{Features of legal regulation of various segments of the market of space services and technologies}

To understand the peculiarities of legal regulation of activity of subjects of WMSST, it must be remembered that the most developed segment of the market of space services and technologies is satellite communications (Merezhko, 1999a). At the same time, in our view, the central problems WMSST of modernity remain unsolved: the definition and delimitation 
of outer space and usage of the geostationary orbit, including consideration of ways and means for the rational and equitable distribution of resources of GSO, to which we must add the problem of legal regulation of LEO.

Analyzing trends WMSST, it is difficult to overstate the exceptional value of GSO for creating modern telecommunication systems. The use of GSO is indivisible with the use of radio frequencies necessary to control the spacecraft (SC) during its launch, to ensure the functioning of SC in geostationary orbit, to transmit useful information to the Earth, and so on. In this aspect, it is also impossible to exaggerate the role of legal regulation of GSO, which is carried out by the International telecommunication union (ITU). I must say that ITU recognized its responsibility in relation to the establishment of a balanced organizational and legal framework for the implementation of activities in the field of space communications in the late 50s. The UNGA, for its part, in 1961, in the above-mentioned resolution 1721 (Goldman, 1980), called on ITU to consider the relevant aspects of international cooperation in the new field of communications.

In 1963, the ITU Emergency administrative conference on radio communications, reviewing the Radio regulations, supplemented the latter with a section that distributed frequencies necessary for use by space systems and communications services, including meteorological and navigation satellites, as well as communications satellites. In addition, perhaps for the first time, an article with definitions necessary for the operation of space systems, services and communication stations appeared in an official international document. At the same time, the Conference continued to base its decisions on the principle of "first come, first served." Therefore, during the application of the necessary frequencies for new communication systems in ITU working body, the International frequency registration Committee (IFRC) to those States and international organizations that first started working on these frequencies ".... permanent privileges and protection were guaranteed, and those who joined later could only use the radio spectrum in such a way as not to interfere with frequencies already registered with the International registration Committee." (Koretskiy, 1989). It was only in 1971 at the ITU World administrative conference, when reviewing the Radio regulations in resolution Spa 2-1 that the provisions concerning guarantees of equal use of the frequency range by States for space communications services first appeared.

Taking into account that the radio frequency spectrum and the geostationary orbit are limited natural resources and should, therefore, be used most efficiently and economically, the 1971 ITU Conference rejected the "right of first" principle and established rules of conduct for space communications, according to which: registration in ITU of frequencies and their use are not a priority for any country or group of countries and do not constitute an obstacle to the creation of space systems by other countries; any country or group of countries that have registered frequencies for space communications services in ITU should implement all feasible measures to ensure that other countries or groups of countries use the new space systems.

In 1973, at the ITU Plenipotentiary Conference, the orbit of geostationary satellites and the frequencies that are provided for its use were declared a limited natural resource that should be used efficiently and economically in accordance with the needs and technical capabilities of States on the basis of the Radio Regulations (Mezhdunarodnoye, 1985). At the same time, ITU has started to apply virtually the same mechanisms to regulate the use of GSO that have developed in the sphere of monitoring the activities of states in the field of radio communications in general. Since 1973, the ITU has granted the International Radio Advisory Committee the right not only to advise on the rational use of the radio frequency spectrum, but 
also to recommend the optimal placement of AES on the GSO, and the International frequency registration Committee, which previously only coordinated the use of radio frequencies, the right to register the orbital positions of these geostationary satellites.

According to article 11 of the Radio regulations (Boguslavskiy, 1998), the coordination procedure, which is used in relation to frequency assignments, and a number of other regulatory mechanisms were extended to the orbital positions of these AES. However, the "limitations" of the unique "natural resource" and the fears of a number of countries regarding the expansion in space by developed countries, including in the direction of using the GSO resource exclusively for their own interests, led to the holding of the conference of equatorial countries in Colombia and the adoption of the Bogotsk Declaration (1976). In this Declaration, Ecuador, Zaire, Indonesia, Colombia, Kenya, the Congo, and Uganda made public claims to "their" segments of the GSO corresponding to their territories along the equator.

However, these claims were rejected by the international community as contrary to the principle of not appropriating any part of outer space. The Declaration did not find the support of other states, and Ecuador, Kenya, Colombia, and Indonesia introduced working paper a and subsequently a draft resolution in the CUOS in 1984, which no longer referred to sovereignty over the relevant segments of GSO, but rather to the establishment of preferential rights that have analogs in the form of rights to exclusive economic zones in the law of the sea, that is, the establishment of a sui generis regime for this unique sector of outer space that would ensure its rational use for the benefit of all countries of the world. However, ITU in its Charter of 22.12.92 fixed this position: "when using a section of frequencies for radio communications, members of the Union should take into account that radio frequencies and the orbit of geostationary satellites are limited natural resources that should be used rationally, efficiently and economically, in accordance with the provisions of the Radio Regulations, in order to ensure equitable access to this orbit and the corresponding frequencies to different countries, taking into account the special needs of developing countries and the geographical location of some countries" (Merezhko, 1999b).

Despite the fact that the question of the legal regime of the GSO and the issue of delimitation of outer space are permanent issues on the agenda of the last 20 years of the UN Committee on outer space and its Legal Subcommittee, the problem of legal regulation of the geostationary orbit, including fair distribution of this "limited natural resource" of Earth is still not solved. ITU's regulation of GSO still has significant shortcomings, which, in particular, leads to the so-called "paper satellite problem." Since the mid-' 80 s, there has been an increasing trend for a number of ITU member states to declare orbital positions, not in order to create their satellite systems based on them, but to turn them into an object of sale (Lukashchuk, 2005). In connection with the creation of increasingly complex navigation systems, security systems in the air and at sea, the deployment of new mobile data transmission systems with extensive use of computers, as well as plans to deploy systems such as global mobile personal satellite communications, the issue of radio spectrum frequency distribution is becoming more acute. The problem of planning and coordinating ITU activities is still quite relevant (Shapira, 1993).

At the end of the $20^{\text {th }}$ century, the share of commercial components in the activities of satellite communications operators increases sharply. Currently, a significant number of international joint ventures, private and public companies that offer a wide range of services in the field of satellite telecommunications on a commercial basis, have appeared and are successfully operating in the global telecommunications market. To obtain a license to create their own satellite systems, private corporations must complete a number of complex legal 
procedures, which include submitting an application for the creation of such a system to the competent state authorities, obtaining permission, as well as coordinating actions with international organizations in order, first, to achieve technical standardization, and secondly, to avoid mutual economic damage. Since the coordination procedure is carried out by the state, private companies must be licensed by the government of a particular country or, at the very least, they must be given protection.

The current situation is unique in that the most international satellite organizations are subject to commercialization processes. Global and regional international satellite organizations (INTELSAT, INMARSAT, INTERSUPUTNIK, EVTELSAT, and others) carry out activities in the field of design, launch, and operation of satellites in geostationary orbit. While carrying out commercial activities, these organizations are engaged in international economic activities. This determines the specifics of the legal framework for the functioning of such organizations, which is based on two fundamental documents: an international convention signed by member states, and an operating agreement signed by national telecommunications organizations designated by the respective governments. However, as a rule, only one satellite operator from each state can be appointed by a country to sign an operating agreement. But the conditions of activity on the world market require improvement of the institutional forms themselves.

Today, the structure of the international satellite communications organization increasingly resembles that of a private company. This is eloquently evidenced by the following facts. Some time ago, the Assembly of INTELSAT parties decided to make several amendments to the Basic Agreement, which will allow each member state to designate several telecommunications organizations to sign the Operating Agreement. A similar decision was taken by the Assembly of EUTELSAT parties. In 1994, following English law, a subsidiary company INMARSAT was formed, which has the status of a private limited liability company. The governing body made such decisions of EUVTELSAT. By 2001, the space and ground segments of this organization must become the property of a newly created private company registered in France. These structural changes in international organizations of satellite communications are caused by increased competition in the international market of telecommunications services, increased technological requirements for satellite systems operated, and, consequently, the desire of these organizations to adequately meet the modern demands of the international telecommunications market (Osnovi, 1993).

However, such transformations do not always occur without complications. For example, the transition of the International space communications organization (ISCO) INTERSUPUTNIK to market principles of activity, which was far from cloudless. For states that, for various reasons, are not ready to accept changes in the organization's operating principles and grant the authority to national operators to sign a new version of the Operating Agreement, the decision of the Council gives the members of the ISCO time to determine before the Protocol is adopted. In our view, it is impossible not to see that there is a problem of the need to establish a conciliation procedure for a number of incongruities and inconsistencies arising from the operation of the two main ISCO agreements. At the same time, the increasing competition in the global space market, the spread of commercialization and privatization processes have put on the agenda the issue of expanding the capabilities of the ISCO System, the acquisition of Communications satellites organization that meet modern requirements for this technology, the invitation to implement joint projects of recognized suppliers of modern equipment and technologies, and the broad involvement of investors. 


\section{The international space station is an example of international cooperation}

In our opinion, the current legal problems that await the participants of the WMSST in the coming years cannot be fully understood without understanding the intergovernmental agreement between the USA, ESA member countries, Canada and Japan on cooperation in the creation of the International space station (ISS), which was concluded on September 29, 1988. Then, in 1988, it was a question of building an American space station, to which the Europeans, Canada and Japan were attracted with their "important elements that together with the base American space station should make up an international space station complex with expanded capabilities" (Klimko et al., 1994). But the scale of this "project of the third Millennium" turned out to be such that even in the expanded structure of the project, participants could not ensure the implementation of the working plans for the construction of the ISS.

Since 1993-1994, Russia has been involved in the discussion of possible participation in the project as the legal successor of the USSR. It has accumulated a wealth of experience (as well as technical potential and trained personnel) in the field of creating and operating manned space stations and practical implementation of long-term missions in outer space. According to the intergovernmental agreement of 1988, although the project theoretically had the status of an international project, it was practically "written according to the American scenario": decisions on all issues were taken collectively, but if the US had its own "point of view", the latter had the upper hand. With the accession of Russia to the project on January 29, 1998, the situation changed: the project acquired a truly international status. This is especially noticeable if we take into account the final formula for making decisions by consensus. And only in cases of inconsistent situations, the final decision is made by the Chairman of the project management Board (representative of the United States), with the possibility of appealing this decision to the program coordination Committee. As a result of more than ten years of negotiations between the delegations of the partner States on the ISS, a system of mutual legal obligations of States and their Executive bodies that regulate the creation and operation of the ISS and its maintenance both in space and on Earth has emerged that is unprecedented in world legal practice.

Conventionally, this system can be imagined as a three-story structure, each of the floors of which regulates its own level of relationships: the highest level — an Agreement between the governments of the project member States, which has accumulated the basic principles of cooperation, as well as mutual obligations of partners in the ISS, which require consolidation by ratification (mutual waiver of liability claims, customs and immigration issues, exchange of data and goods, intellectual property protection, criminal jurisdiction at the station, etc.); the Agency level - several bilateral memoranda of understanding between the central Executive bodies of partner States, space agencies and the third level — the level of Individualscosmonauts, the leading operators of the ISS for the nearest period.

The code of conduct for cosmonauts is intended to regulate the rights and obligations of members of the international crew of the station has just appeared. Still, its appearance has caused a mixed reaction even among theorists who have a mediated relationship to human-crewed missions in space. This is not surprising. In contemporary international law regulating the rights and duties of members of the international crews is one of the most complex and contradictory: special conditions of space missions require, on the one hand, the implementation of the principle of unity of command (the unconditional implementation of 
the orders of the commander of the crew, especially in extreme and emergency situations), on the other, the question of the limits of authority of the commander, the level of responsibility for their decisions and, even, possible measures of coercion, which the commander may apply to the members of this crew who refused to comply with its orders; to these problems, the problems of regulating the relationship between the state of registration of a manned space vehicle and a foreign or international element regarding the parties' definition of lex causae are added.

As already noted, the project provides for the design, production, and operation of the ISS for various needs in the field of basic scientific research, the development of new and practical use of space technologies; full (to a greater extent commercial) use of information from Earth's orbit for the needs of a number of sectors of the economy: nature management, ecology, resource support, disaster issues, and many others). And on the basis of the directions of use of the ISS, and considering the provisions of Section 101 "Commercialization of the space station," the last Act of the USA on the commercialization of outer space October 28, 1998 (An Act, 1998), we can talk about further spread of the commercialization of outer space, the inclusion of individual activities on Board manned space stations to areas WMSST. And, of course, about the need in the near future (2002-2005) to solve international legal and private law problems of regulating relations on this rather insignificant in volume, but very important in the weight of the results of activities (including for other areas) of the WMSST sector. Issues such as: "jurisdiction and control" over the national space segment and off-Earth crew members; "relations between the state of registration and a foreign or international element": what right to apply if the legal situation, regulated by private international law, whether on a manned object or outside of it in outer space?; "property right" (it refers to inventions and discoveries in the course of space activities outside the Earth), etc. In our opinion, the issues of preserving the right to intellectual and industrial property created on Board the ISS are particularly important, taking into account the problems of WMSST.

\section{Conclusions}

So, analyzing the law-making activities of international organizations in the light of the effectiveness of the mechanisms of legal regulation of WMSST and taking into account changes in the property market both through commercialization and privatization of space activities, the involvement of new stakeholders in these activities, and globalization of the market, it should be noted that the last 20-30 years, there has been some consistency problem (lack of coordination) of normative activities of international institutions at various levels. In addition to the UN Committee on outer space and its subcommittees, international specialized organizations of the UN system (ITU, UNESCO, WIPO), intergovernmental and special organizations (International Institute for the unification of private law, INTELSAT, INMARSAT), nongovernmental organizations (International institute of space law, International law association, Committee on space research of the International Council of scientific unions) and regional organizations (European space agency, European satellite communications organization, the European organization for the exploitation of meteorological satellites) and the like today pay attention to the issue of improving legal regulation of relations in WMSST.

Thus, by expanding the horizons of international cooperation in the field of space activities and the use of space technology to meet the urgent needs of the world community, these organizations also add their significant contribution to the development of the ISL. 
The problem of coordinating the law-making activities of these authoritative international organizations has been repeatedly highlighted in UNISPACE III documents. As a result of this lack of coordination, "international space law is becoming increasingly fragmented and, in some areas, inconsistent." In our view, significant efforts are required on the part of the international community to coordinate the efforts of all components of the global legal order in the space industry with a view to further progressive development of the ISL, as well as to bring normative work into line with a single process under the auspices of the UN.

\section{[미] References}

An Act To encourage the development of a commercial space industry in the United States, and for other purposes (1998) Oct. 28. https://www.nasa.gov/offices/ogc/commercial/ CommercialSpaceActof1998.html

Boguslavskiy, Mark (1998) Mezhdunarodnoye chastnoye pravo. Yurist.

Oprishko, Vitaliy (1995) Mizhnarodne yekonomíchne pravo. Libíd.

Denisov, Volodymyr (1992) Razvitiye teorii $i$ praktiki vzaimodeystviya mezhdunarodnogo prava $i$ vnutrennego prava / Realizatsiya mezhdunarodnopravovykh norm vo vnutrennem prave. Naukova dumka.

Goldman, Berthold (1980) La lex mercatoria dans les contrats et l'arbitrage internationaux : réalité et perspectives. In: Droit international privé : travaux du Comité français de droit international privé, 2e année, 1977. pp. 221-270. https://doi.org/10.3406/ tcfdi.1980.1843

Klimko, G., Pavlyuk, V., Krasil'chuk, V., and Dídkovs'kiy, M. (1994). Problemi íntegratsî‘ Ukraini v mízhnarodniy podil pratsí. "Poserednik".

Koretskiy, Volodymyr (1989) Izbrannyye trudy, Kn. 1. Naukova dumka.

Lukashchuk, Igor (2005) Mezhdunarodnoye chastnoye pravo: Obshchaya chast' . Volters Kluver. http://www.cawater-info.net/bk/water_law/pdf/lukashuk_1.pdf

Merezhko, Alexander (1999a) Lex mercatoria - teoriya i printsipy transnatsional'nogo torgovogo prava. Takson.

Merezhko, Alexander (1999b) Mezhdunarodnoye chastnoye pravo na poroge XXI veka: problemy i perspektivy. Yuridicheskaya praktika, № 22. pp. 1-4.

Mezhdunarodnoye chastnoye pravo (1985) Redaktor profesor G. K. Matveyeva. Vishcha shkola.

Osnovi yekonomíchnoîteoriî"(1993) Za red. S.V.Mochernogo. "Tarneks".

Problemi garmonizatsií zakonodavstva Ukraîni z mízhnarodnim pravom. Materíali naukovopraktichnoi"konferentsiî"(1998) "Kniga".

Shapira, Z. (1993) Mezhdunarodnoye pravo predprinimatel'skoy deyatel'nosti. "Progress Univers". 